\title{
Recent Trends in Occupational Injuries and Diseases in Argentina: A Panel Data Approach
}

\author{
Valentina Viego, Nicolas Sagui \\ Department of Economics, Universidad Nacional del Sur, Bahía Blanca, Argentina \\ Email: vviego@criba.edu.ar, saguinicolas@gmail.com
}

Received 13 October 2015; accepted 24 November 2015; published 27 November 2015

Copyright (C) 2015 by authors and Scientific Research Publishing Inc.

This work is licensed under the Creative Commons Attribution International License (CC BY). http://creativecommons.org/licenses/by/4.0/

c) (i) Open Access

\begin{abstract}
Occupational injuries pose major public health and development related problems. However, efforts towards identification of determinants of labor incidents among salaried workers are still scarce in developing countries. This study aimed to identify sector and time effects on occupational accidents and diseases among Argentinean workers during 2004-2013. A negative binomial panel data model is estimated based on official data on injuries and fatalities in workplaces collected by the Board of Occupational Risks. Business cycle and profitability indicators are used as explanatory variables. Estimations also are adjusted by sector and time effects. Argentina business cycle tends to be negatively related with occupational injuries rates. In contrast, accidents at work reported tend to exhibit longer losses in working days. We also find a positive relationship between profitability and fatal injuries. These results may suggest incentives for under reporting and lower investments in safety by more profitable activities, which can imply some level of endogeneity between profit rate and occupational injuries.
\end{abstract}

\section{Keywords}

Occupational Injuries, Occupational Risk Law, Panel Data Model, Argentina

\section{Introduction}

Occupational injuries and diseases constitute an important aspect of the social question; when working adversities occur (whether by accident or illness caused in working places or on the way to the work), the victim suffers a concrete injury that prevents him from living with the same previous conditions.

According to worldwide International Labor Office (ILO) figures, each year more than 270 million workers 
suffer accidents in the workplace and around 160 million develop occupational diseases. Of these, more than 2 million die (1\% of accidents and $0.4 \%$ considering all types of contingencies) [1]. Thus, labor kills about 5500 wage earners a day. The consequences are not only negative for the victims; ILO estimates indicate that about $4 \%$ of the annual gross domestic products are lost by direct and indirect costs arising from occupational accidents and diseases. However, these data are incomplete since no statistics are available from claims incurred among unregistered workers.

In Argentina, near 650,000 employees suffer annually work-related injuries. In daily terms, around 1800 workers suffer occupational injuries and diseases, $75 \%$ of them occur in workplaces, $16 \%$ take place on roads, $5 \%$ are aggravations from previous injuries and the rest (3\%) comprise diseases. Although incidence rates show a decreasing trend since 2006, some particulars exhibit an ever increasing trend during the last 15 years.

According to the general duty "not to harm", causing damage gives any citizen the right to claim to justice for reparation by the responsible. In practice, the restoration has led to the emergence of specific laws that establish minimum safety standards for workplaces and responsibilities in repairing damage occurred in workplaces.

In Argentina, the law of occupational risks and its operative rules constitute the public response to the problem. Since 1996 that system is based on compulsory insurance of employees.

The aim of this paper is to analyze the sector components and the recent temporal evolution of labor accidents in Argentina for the period 2004-2013 and to evaluate the role of business cycles and profitability in occupational injuries rates.

The paper is organized as follows: section following a brief overview of the regulatory context of occupational injuries in Argentina is presented. The empirical literature that identifies the determinants of health and safety is then summarized. The following section presents information sources available in Argentina. The following sections present the estimation strategy, results and discussion and finally the main conclusions.

\section{Institutional Framework}

A system of workplace hazards should aim to reduce accidents at work through risk prevention on the working activity and repairing damage from accidents and illnesses.

In Argentina, the first legal precedent on accidents and occupational diseases is the Law No. 9688 approved in 1915. That norm was in force until 1991, which was replaced by Law No. 24028, which did not involve substantial changes from the original. Both laws watched the "dual track", meaning that when a worker is a victim of an accident he can recourse either to civil or to labor courts.

In 1995 the Law No. 24457 known as Occupational Risk Law (hereinafter ORL), currently in force, established the deep reforms in foundations of the system of protection of workers against occupational accidents and diseases. The new legislation adhered to a market oriented vision for the functioning of the system as it established the creation of work injury insurers, private for-profit organizations whose purpose would be to promote the prevention of occupational misfortunes and provide benefits to workers who were suffering illnesses or accidents caused by working activities.

The ORL' objectives are: Compensate the damages caused by occupational diseases or accidents, including the rehabilitation of the injured worker; Reduce occupational accidents and diseases through prevention; Promote professional retraining and relocation of the injured worker.

Encourage collective labor bargaining for improvements in prevention measures and remedial services.

The individuals reached this law are workers of the private sector, officials and employees of the national, provincial and municipal public sector, and in general all required to provide a public service charge.

The existing rule establishes a compulsory insurance for employers, managed by insurance private companies. Insurers must give the victim of contingencies two types of compensations in exchange for a fare. The first one are compensations in kind (medical, pharmaceutical, orthopedic, rehabilitation and funeral service, Art. 20 ORL) and, secondly, cash compensations (Arts 11 - 19 ORL).Medical in kind benefits are aimed at healing the worker and, if possible, returning to work in the pre-contingency condition or retraining for other tasks.

Simultaneously, the sick or injured worker begins to also receive cash benefits for his inability, replacing the remuneration prevailing before the accident or illness occurred. The basis for calculating cash benefits is the registered monthly salary. High levels of informality in the payroll in Argentina, make that cash compensations do not equate to the pre-accident wages. 
The ORL initially classify the situation of the worker as temporary incapacity (Art. 7 ORL), which may cease by medical release, declaration of permanent incapacity or by death of the invalidated. During the period in which it is declared the temporary incapacity the worker must receive necessary medical care and a monthly monetary compensation equivalent to the salary previous to the contingency.

In turn, permanent work disabilities are classified in degrees (see Table 1$)^{1}$. Physical damage is quantified as a percentage of disability determined in an administrative procedure developed by committees of medical professionals (Art. 21 ORL).

Table 1 shows that, during 1996 and $2012^{2}$, in cases where the disability exceeded 50\%, the worker received for at least three years $70 \%$ of his previous wage weighted by the percentage of disability (Art. 14 ORL). Thus, a worker who has lost $52 \%$ of his operational capacity should receive a life income equivalent to $36 \%(0.7 \times 0.52$ $=0.36$ ) of his previous salary. In many cases the annuity established by the ORL was lower than the minimum pension or than minimum wage [2].

In the case of confirmed permanent disabilities (i.e., until 2012-2014 that period could last up to 3 years) the ORL provided compensation in single payment (Arts. 11 and 14 ORL).

If the final permanent disability exceeds $66 \%$, the worker is considered totally disabled and the ORL orders his retirement and his entry to the pension system compensated with lump sum compensation (with maximum amount). This clause affects younger workers because once that the annuity is exhausted, it ceases to be paid.

A 2007 report of the Argentinean Workers Union (hereinafter CTA by its initials in Spanish) realizes that in several cases the benefits have been so petty (when they were not directly denied by the insurer, appealing to ignore as occupational certain accidents or diseases) that have left victims in situations of need and neglect unacceptable in a state of law, violating minimum guaranteed living conditions.

Also the ORL excludes from insurers' compensation accidents caused on purpose by the employer.

The ORL also establishes workers compensation for occupational diseases. But instead of establishing an

Table 1. Rates compensations set by Laws No. 24557 and 26773.

\begin{tabular}{|c|c|c|c|c|c|}
\hline \multirow{2}{*}{ Compensation, C } & \multirow{2}{*}{$\begin{array}{l}\text { Temporary } \\
\text { disability }\end{array}$} & \multicolumn{3}{|c|}{ Permanent disability } & \multirow[t]{2}{*}{ Death } \\
\hline & & Partial $\leq 50 \%$ & Partial 50\% - 65\% & Total $\geq 66 \%$ & \\
\hline In kind & $\begin{array}{l}\text { medical \& pharmac } \\
\text { assistance }\end{array}$ & $\begin{array}{l}\text { medical \& pharmac } \\
\text { assist }\end{array}$ & & & funeral \\
\hline Provisory & $C=w$ & & $\begin{array}{l}\mathrm{C}=\mathrm{w} \times 0.7 \times \mathrm{D} \\
\text { abolished since } \\
2012\end{array}$ & $\begin{array}{l}\mathrm{C}=0.7 \times \mathrm{w}^{* *} \\
\text { abolished since } \\
2012\end{array}$ & Annuality: \\
\hline Final (after 3 years) & - & $\begin{array}{l}C=53 \times w \times D \times \\
65 / A\end{array}$ & $\begin{array}{l}\text { Up to } 2012 \\
\text { Monthly payment: } \\
\mathrm{C}=\mathrm{w} \times \mathrm{D}\end{array}$ & $\begin{array}{l}\text { Final retirement } \\
\text { plus } \\
\mathrm{C}=53 \times \mathrm{w} \times 65 / \mathrm{A}\end{array}$ & $C=53 \times w \times 65 / A$ \\
\hline Fixed amount: & & & $\begin{array}{l}\text { up to } 2000 \text { : } \\
\text { u\$ } 30000 \\
\text { 2009: u\$ } 21447 \\
\text { 2012: u\$ } 40207\end{array}$ & $\begin{array}{l}\text { up to } 2000 \text { : } \\
u \$ 40000 \\
\text { 2009: u\$ } 26809 \\
\text { 2012: u\$ } 50313\end{array}$ & $\begin{array}{l}\text { up to } 2000: \\
\text { u\$ 50000 } \\
\text { 2009: u\$ } 32170 \\
\text { 2012: u\$ } 60420\end{array}$ \\
\hline $\begin{array}{l}\text { Other injuries } \\
\text { (moral } \\
\text { psychological, } \\
\text { etc.) }\end{array}$ & & & $\mathrm{C} \times 0.2$ & $\mathrm{C} \times 0.2$ & $\mathrm{C} \times 0.2$ \\
\hline $\begin{array}{l}\text { Limits in } \\
\text { compensations }^{* * *}\end{array}$ & & $\begin{array}{l}\text { up to } 2000: \text { Max } \\
\text { u\$ } 180000 \times \text { D } \\
\text { 2009: Min } \\
\text { u\$ } 48256 \times \text { D } \\
\text { 2012: Min } \\
\text { u\$ } 82211 \times \text { D }\end{array}$ & $\begin{array}{l}\text { up to } 2000: \text { Max } \\
\text { u\$ } 180000 \times \text { D } \\
\text { 2009: Min } \\
\text { u\$ } 48256 \times \text { D } \\
\text { 2012: Min } \\
\text { u\$ } 82211 \times \text { D }\end{array}$ & $\begin{array}{l}\text { up to 2000: Max } \\
\text { u\$ } 180000 \\
\text { 2009: Min } \\
\text { u\$ 48256 } \\
\text { 2012: Min } \\
\text { u\$ } 82211\end{array}$ & $\begin{array}{l}\text { up to 2000: Max } \\
\text { u\$ 180000 } \\
\text { 2009: Min } \\
\text { u\$ 48256 } \\
\text { 2012: Min } \\
\text { u\$ 82211 }\end{array}$ \\
\hline
\end{tabular}

$\mathrm{w}$ = formal monthly wage; $\mathrm{D}=$ percentage disability; $\mathrm{A}=$ age at injury. ${ }^{*}$ Excludes injuries on the way to work. ${ }^{* *}$ If disabled worker needs permanent assistance in daily routine, payment includes an additional. Amounts varied between 2000-2012; in 2000 the extra payment was equivalent to one minimum pension in 2009, the amount was near u\$536. ${ }^{* * *}$ Since 2012 single payment and minimum compensations are revised twice a year. Compensations are set and paid in local currency. Rates were converted to dollar using official exchange rates for comparative purposes. Source: own based on laws and regulatory decrees.

\footnotetext{
${ }^{1}$ Moreover, this declaration is temporary during 3 years, term during which medical committees can reconsider the situation of the injured worker. Once this term passed, the permanent incapacity the case is closed.

${ }^{2}$ In fact, until April 2014, as Law No. 26773 was put into effect 18 months after its approval.
} 
evaluation mechanism settled on case by case basis to determine the causal link between workers' occupation and his disease, it is governed by a narrow list of pre-set diseases by sector. The initial (narrow) catalog was set by Decree No. 658/1996, which was in force during 16 years. After the 2012 reform to the ORL, that record can be revised on annual basis. Anyway, the ORL excludes many diseases of any type of coverage. The market orientation of the Occupational Safety and Health (hereinafter OSH) system has generated new medical practices under which pathologies that were traditionally linked to labor conditions (e.g. umbilical hernia or spinal related diseases) have now failed to recognize that origin, although in the case of workers whose jobs demand much greater efforts than normal ones [3].

While ORL provides for review of disability decided by medical committees in judicial instance (to federal court or to a central medical commission), the use of this mechanism is in practice non-existent; revisions do take place if injured workers have appropriate legal advice guiding them in the use of most convenient resources. In addition, the State bodies responsible for reviewing claims are located in the city of Buenos Aires, imposing geographical barriers to the use of those procedures, forcing many workers to litigate hundreds or even thousands of kilometers from their place of residence or work. On the contrary, these barriers do not operate for insurance companies, which have all headquartered in the capital city.

The fact that the worker dissatisfied with the decision of the medical commissions of the insurers must accost to the federal and not specialized courts (usually linked to crimes and misdemeanors unrelated with labor issues) seriously affects the right to defense.

In particular, Article 39 of the ORL set up a closing mechanism that denied the worker the right to go to civil courts in order to access to full compensation for damages and also exempt the employer from liability, except contingencies caused by fraud. Therefore, the former version of Law No. 24557 considered only compensations set by fees (based on percentage of disability, age and wage) without allowing for other damage that can be repaired (psychological, moral etc). Outside of litigation related to the disability percentage calculation, wages included as a basis calculation or willful misconduct of the employer, until 2012 the ORL did not allowed legal claims carried by workers victims of accidents or illnesses. In other words, the legislation coming into force in the mid-90 s canceled the "dual track" by prohibiting access to the victim's civil action.

That situation led to an increase in lawsuits discrediting the system' coherence with constitutional norms (files Gorosito in 2002; Castillo in 2004, Aquino in 2004, Llosco in 2007, etc). While the Supreme Court of Justice dismissed the first questioning, after the change in the composition of the court in 2004 it began to accept the arguments presented to judges against the constitutionality status of the ORL and the incongruity of the ORL with the international obligations assumed by Argentina in human rights treaties.

Thus, the decisions of the Supreme Court in the cases of Castillo, Aquino, Milone and Llosco explicit the criteria that local legislation should adopt in order to be reach the provisions of international human rights laws. Thus, the Supreme Court declared the unconstitutionality of Articles 6 (establishing a closed list of compensable diseases), 14, 15 and 18 (determined maximum amounts for repairing formulas, compensations in the form of an annuities), 21 (operation of medical commissions), 39 (exemption from liability of the employer), and 46 (intervention of federal courts over provincial jurisdictions). However, in Argentina the rulings of the Supreme Court have no derogatory effects and take effect only in the specific case.

Insurers are not directly affected by these actions because they are ordered, at worst, to pay the sums set up by the ORL or single payment; lack of full compensation for occupational accidents and diseases result in the prosperity of the business of insurance companies [2].

The State behavior has been schizophrenic for more than 8 years, since the first rulings of the Supreme Court [2] because while the judiciary pointed out the inconsistency of the system of labor risks with international standards, the remaining branches of government failed to adapt provisions. Thus, each particular case dissatisfied with compensation for damages caused by accidents or illness had to come up to the Supreme Court.

In 2012, the Law No. 26773 approved several changes in $\mathrm{OSH}^{3}$ (Table 2). One of the main changes is the treatment of litigations related with occupational diseases or accidents in civil courts, instead of federal justice and the option clause. Thus, injured or ill workers unsatisfied with the compensation offered by the insurer can now appeal to civil justice, waiving for any amount offered by the insurer. On the contrary, the receipt of cash compensations is considered as acceptance of any amount and rejection to claim through courts.

Several authors believe that the new competence of civil courts and the option clause implies a lessening in

${ }^{3}$ The Law was not regulated until April 2014, so its main impacts could be assessed only after that date. 
Table 2. 2012 Main reforms to Occupational Risks Law.

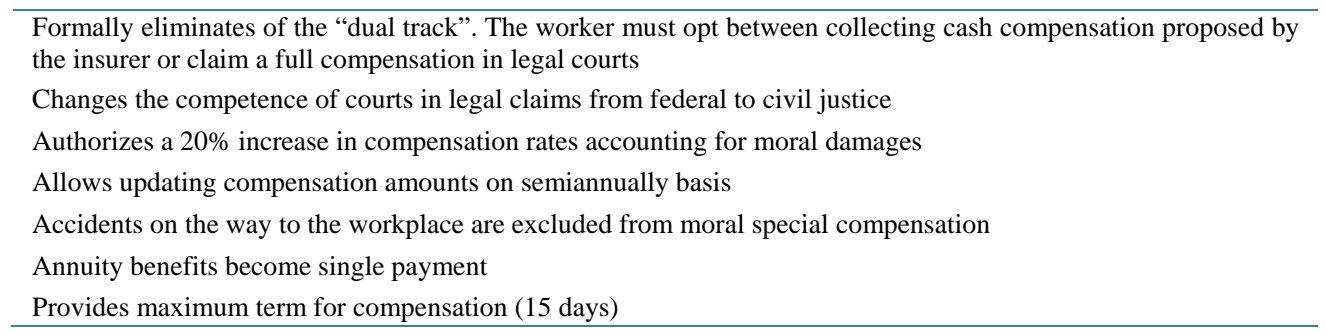

Source: own based on Law No. 26773.

the defense capabilities of the worker for 2 reasons; civil courts are less specialized than labor courts and, hence, attend more cases. For that reason, the time resolution of a civil trial is considerably higher than a case filed in labor courts. Second, civilian judges are less familiar with the protective principles of labor laws and they not necessarily take into account the state of extreme need or asymmetries between workers and employers, a basic principle of labor norms.

Another questioned aspect of the reform of 2012 is the term of 15 days to settle the monetary compensation. This expiring date looks favorable to the worker but actually puts him at a crossroads in deciding which (civil or labor) legal regime is more suitable to defend his rights, because if he collects compensation from the insurer is implicitly applying the right of option, rejecting thus his right to claim a full compensation for damage.

Low amounts offered by insurers usually tempt the worker, either by ignorance or extreme need, to accept the proposal without being fully aware that he may be being harmed compared to what would have obtained by full compensation on civil courts. The reform assumes the fiction that the victim consciously analyze the most convenient and rational regime.

The Argentinean ORL and reforms introduced in 2012seem more oriented to reduce employers' liabilities and subsequent justice litigation rather than preventing occupational injuries and disabilities and/or promoting OSH. Increasing compensations does not contribute per se to rising occupational safety in the workplace. [4] propose a formal model in which compensation for accidents at work generate conflicting incentives for employers and workers; on the one hand, the prospect of higher compensations emerging from occupational injuries induce workers to take on more risks, while encourages companies to increase security. Then the economic theory is ambiguous about the impact of compensations on occupational hazards. In addition, [5] warn that the level of compensation for working can alter the incentives for reporting accidents without changing the true level of safety in workplaces. As with safety standards, reporting incentives are opposite between firms and workers; more generous compensation stimulate more reporting on workers (off-the job injuries as occurring at work, reporting injuries that wouldn't be reported in the absence of insurance coverage). On the contrary, higher compensations induce firms and insurers to under report occupational injuries.

The entry of private agents (insurers) for monitoring compliance and safety management in workplaces and repairing damage from accidents and occupational diseases was founded on the argument that this type of organization, which consider the compensations for occupational damages as a cost and search also maximum benefits as any for profit organization, would lead to the socially desirable outcome of reducing occupational accidents. However, like any private company that seeks to obtain the greatest possible benefits, the objective function of the insurer includes costs (compensations plus administrative overhead costs) and revenues (premiums collected). As employers are clients of the insurer, if the insurer exerts excessive pressure to the insured to make investments oriented to reduce occupational risks, it may lose lax customers and thus reduce its revenue. Consequently, the insurers' incentive to forcing the insured to get safer work environments for staff is only partial and should be compared to the probability of hiring a less severe insurer by the client. The last aspect highlights that insurers compete for clients, not on absolute but on relative prices (price weighed by control laxity) ${ }^{4}$. In short, business objectives place insurers' decisions on a vector of affiliates and risks based on shareholders' appetite for gains that do not necessarily minimize workplace accidents ${ }^{5}$.

In turn, another strategy used by insurers to avoid increasing costs based on "excessive" compensations for injured workers is to induce medical commissions avoiding the acknowledgment of disability in affected work-

\footnotetext{
${ }^{4}$ Rates are regulated by the BOR.

${ }^{5}$ The same logic operates in insurers of car accidents, whose goals do not necessarily induce safe conducts in drivers.
} 
ers (e.g. transferring to medical evaluator additional fees for underregistration of disabilities).

The impact of labor risks systems based on private insurers bears particularly scrutiny because at the same time it creates a compensation mechanism for workers, it reduces the incentives for firms to improve workplace conditions by reducing their liability [6]. This creates a situation of "moral hazard" for the employer as well as for the employee to reduce safety at work. Thus economic incentives need to be coupled and/or substituted with improvement in resources and capacity of the public sector surveillance and enforcement system.

\section{Background Literature}

Empirical studies on determinants of labor accidents applying multivariate statistical methods in large samples are concentrated mainly in developed countries. The empirical literature on occupational accidents referred to less developed countries is less abundant and refers to a considerably lower number of countries [7] and [8] for Ethiopia; [9] for Taiwan; [10] and [11] for Spain; [12], [13] and [14] for Brazil; [15] for Iran).

In Argentina the few studies on occupational injuries that have been published refer to a limited number of sectors ([16] in truck drivers; [17] for the case of teachers or [18] in veterinarians). Another feature of that evidence is its qualitative nature (see, for example, case studies reported by [19]).

Work-related injuries indicators collected by ILO are restricted to a few number of countries and they are not always comparable ${ }^{6}$. Estimations carried out by [20] that $85 \%$ of deaths in workplaces are caused by occupational diseases. Also, figures differ between less developed and developed economies; in LDCs accidents rates are significant higher than diseases. Fatal injuries are more related with labor intensity regimes than with level of development; Asia and Subsaharan countries show the highest incidence followed by Latin American countries, Middle East Europe and finally OECD countries (Table 3).

In particular, [13] found a risk of death in steelworkers higher than that observed for developed countries. This situation increases the role of the worker's health status on the probability of labor fatalities, offsetting the risks of a less secure environment.

One of the most striking findings is that education per se fails to reduce accidents when risks in the workplace are high and the use of appropriate tools in safe environments is limited [21].

Finally, there is a long tradition in the study of the relation between the economic cycle and workplace accidents. The roots of this tradition go back to [26] that found a pro-cyclical relation between (reported) injuries and employment in manufacturing sector in the US. This relation was attributed to a number of reasons that can be summarized as follows:

Job tenure: in periods of economic upturns labor demand is increasing and more inexperienced workers are hired; these workers are also the first to lose their jobs in downturns. Therefore the average job tenure decreases in upturns and occupational injuries increase as a result of low experience and less time to training [27].

Work intensity: in economic upturns, work intensity increases to meet demand, which results to an increase of accidents at work.

Vintage capital: in economic upturns, all resources, including redundant resources (such as old unsafe machinery) are put in full use in order to meet demand. Such unsafe equipment results to an increase of accidents at work.

Reporting: during downturns workers are less willing to report accidents due to fear of losing their jobs.

A large part of the relevant literature confirms the hypothesis for a pro-cyclical nature of workplace accidents (see review in [28]).

Intuitive arguments tend to favor a pro-cyclical hypothesis for the relation between business cycle and labor accidents; when economic activity increases, employment expands in hazardous industries, overtime increase rising also worker's fatigue, less maintenance operations are held so older and less safe equipment is used, more workers inexperienced are hired, etc. all favoring increasing on work accidents rates. Also, during economic upwards salaries are more tighten to productivity, stimulating workers to under estimate risks, searching forbetter salaries.

However, this statistical relation faced a lot of different and sometimes controversial explanations. Another part of the relevant literature stresses the issue of accident under-reporting [29], arguing that this pro-cyclical behavior of accidents is rather emerging from under reporting than from actual less incidence. In the same vein,

\footnotetext{
${ }^{6}$ Japan and other Asian countries report incidence rates in terms of hours worked, some European countries report occupational injuries in
} terms of full time employees. 
Table 3. Occupational injuries by selected countries 2007.

\begin{tabular}{|c|c|c|c|}
\hline & $\begin{array}{c}\text { Fatal injuries } \\
\text { (per } 100000 \text { workers insured) }\end{array}$ & $\begin{array}{c}\text { Non-fatal injuries } \\
\text { (per } 100000 \text { workers insured) }\end{array}$ & $\begin{array}{l}\text { Days lost by temporary incapacity } \\
\text { (million) }\end{array}$ \\
\hline Argentina & 14.1 & 8250 & 17.82 \\
\hline Australia & 2.0 & 1030 & $\mathrm{n} / \mathrm{d}$ \\
\hline Canada & 2.3 & 1607 & $\mathrm{n} / \mathrm{d}$ \\
\hline Costa Rica & 9.9 & 13927 & 2.77 \\
\hline France* & 3.4 & 3943 & 35.87 \\
\hline Germany & 2.2 & 2803 & $\mathrm{n} / \mathrm{d}$ \\
\hline Hong Kong (China) & 6.6 & 1682 & 0.39 \\
\hline India* & 116.8 & 325 & $\mathrm{n} / \mathrm{d}$ \\
\hline Ireland & 2.8 & $1350^{* * *}$ & $\mathrm{n} / \mathrm{d}$ \\
\hline Israel & 2.6 & 2313 & 2.23 \\
\hline Mexico & 9.0 & 3120 & $\mathrm{n} / \mathrm{d}$ \\
\hline New Zealand & $\mathrm{n} / \mathrm{d}$ & $\mathrm{n} / \mathrm{d}$ & 2.07 \\
\hline Portugal & 6.3 & 3965 & $\mathrm{n} / \mathrm{d}$ \\
\hline Russian Federation & 12.4 & 262 & 2.72 \\
\hline Spain & 3.6 & 5748 & 21.56 \\
\hline Sweden & 1.7 & 674 & $\mathrm{n} / \mathrm{d}$ \\
\hline Switzerland & 1.6 & 2270 & $\mathrm{n} / \mathrm{d}$ \\
\hline Turkey & 12.3 & 23 & 1.88 \\
\hline United States & 4.0 & $\mathrm{n} / \mathrm{d}$ & $\mathrm{n} / \mathrm{d}$ \\
\hline
\end{tabular}

${ }^{*}$ Figures differ by source. ${ }^{* *}$ Per workers employed. Source: ILO, LABOURSTA.

[30] argue that the changing conditions in the labor market in the US in the 90s are not consistent with the situation of occupational accidents. Indeed, the US Bureau of Labor Statistics and workers' compensation insurers reported dramatic drops in rates of occupational injuries and illnesses during the 1990s. Simultaneously, during the 1980s and 1990s precarious employment rose, wages and opportunities decreased and the population of immigrant workers increased. Those changes probably created incentives for preventing vulnerable employees from reporting some injuries and illnesses. Also, changes in the health care system, including loss of access to health care for growing numbers of workers and increased obstacles to the use of workers' compensation, compounded these effects by preventing the diagnosis and documentation of some occupational injuries and illnesses. That situation can explain why [29] find that the probability of reporting injuries fall in unemployment upwards. More specifically, they argue that data of fatal accidents are more reliable as they are less susceptible to under-reporting and these data show no relation to economic cycles [31]. In favor of a counter-cyclical nature of labor accidents, [32] suggests that during periods of economic expansion, workers are better able to resist the introduction of unsafe working practices or work intensification by managers.

Thus, the counter-cyclical relation between business cycle and occupational injuries that most recent empirical studies tend to find is usually associated with less favorable working conditions (more instability, informality, precarious labor intensity, etc.), usually leading to underreporting of accidents (especially the more severe or those involving loss of working days), even in phase of increasing employment levels.

[28] Tried to explain these controversies, assuming that both hypotheses are simultaneously valid and the total effect is the resultant of their combinational impact. In sum, there is no expected sign for the relationship between occupational injuries and business cycle. Main predictors of occupational injuries used in empirical studies are reviewed in Table 4. 
Table 4. Predictors of occupational injuries in empirical studies based on microdata.

\begin{tabular}{|c|c|c|}
\hline & Hypothesis & Evidence \\
\hline \multicolumn{3}{|l|}{$\begin{array}{l}\text { Individual } \\
\text { characteritics }\end{array}$} \\
\hline Age & $\begin{array}{l}\text { Proxy for expertise and/or experience. Younger } \\
\text { workers tend have higher propensity to suffer labor } \\
\text { accidents. }\end{array}$ & $\begin{array}{l}\text { workers under } 30 \text { y. o. have higher labor risks } \\
\text { [21]. }\end{array}$ \\
\hline Sex & $\begin{array}{l}\text { Men are more exposed than women to occupational } \\
\text { risks. }\end{array}$ & $\begin{array}{l}\text { Women working in informal position have higher } \\
\text { probability of suffering an accident in workplace } \\
\text { [14]. } \\
\text { Men experience more occupational risks [21]. }\end{array}$ \\
\hline \multicolumn{3}{|l|}{ Individual risk fators } \\
\hline Stress & $\begin{array}{l}\text { Stressed workers exhibit more losses of attention and } \\
\text { failures in working routines. }\end{array}$ & Confirmed by [21] \\
\hline Job satisfaction & Dissatisfaction with job. & $\begin{array}{l}\text { [7] Finds supportive evidence for coal workers in } \\
\text { Ethiopia. } \\
\text { [9] Finds supportive evidence in non fatal injuries } \\
\text { for petrochemical workers in Taiwan. }\end{array}$ \\
\hline Sleeping disorders & $\begin{array}{l}\text { Workers that do not sleep sufficient time pay less } \\
\text { attention to every day routines and expose more to } \\
\text { risks. }\end{array}$ & $\begin{array}{l}\text { Confirmed by [21] [16]. } \\
\text { Find supportive evidence in transportation workers } \\
\text { in Argentina. }\end{array}$ \\
\hline \multicolumn{3}{|c|}{ Contracting practices } \\
\hline $\begin{array}{l}\text { Term (temporary- } \\
\text { fixed vs. endless) }\end{array}$ & $\begin{array}{l}\text { Temporary contracts reduce incentives to invest in } \\
\text { specific skills increasing occupational injuries. } \\
\text { Also, wages based on performance encourage labor } \\
\text { intensity and working hours increasing the time of } \\
\text { exposure. }\end{array}$ & $\begin{array}{l}\text { [10] Finds that workers with short-term contract } \\
\text { have higher probability of experience accidents in } \\
\text { work. } \\
\text { [11] Finds that temporary workers increases the } \\
\text { incidence of non fatal injuries and that fixed term } \\
\text { contracting rises occupational diseases. }\end{array}$ \\
\hline Formal hiring & $\begin{array}{l}\text { Companies hiring non formal workers invest less in } \\
\text { safety working places. }\end{array}$ & $\begin{array}{l}\text { [14] Finds support in non fatal occupational inju- } \\
\text { ries. }\end{array}$ \\
\hline Subcontracting & $\begin{array}{l}\text { Subcontracting increases the incidence of occupation- } \\
\text { al accidents and sickness as the number of agents } \\
\text { involved is higher, their responsibility is less clear and } \\
\text { more difficult to control. }\end{array}$ & $\begin{array}{l}\text { [22] Finds that subcontracting workers have a } \\
\text { higher risk of work-related diseases and a higher } \\
\text { absenteeism rate than parent firm workers. }\end{array}$ \\
\hline \multicolumn{3}{|l|}{ Sector circumstances } \\
\hline Business cycle & $\begin{array}{l}\text { Pro-cyclical; the number of accidents tend to increase } \\
\text { during economic upwards and viceversa. } \\
\text { Counter-cyclical; in economic downturns firms are } \\
\text { less willing to invest in safety workplaces and injuries } \\
\text { incidence increase. }\end{array}$ & $\begin{array}{l}\text { [23] Finds pro-cyclical relationship in minor inju- } \\
\text { ries. No significant relationship was found in ma- } \\
\text { jor injuries. } \\
\text { [24] Find pro-cyclical behavior in fatal and non } \\
\text { fatal occupational accidents in } 6 \text { European coun- } \\
\text { tries. }\end{array}$ \\
\hline Profitability & $\begin{array}{l}\text { Negative; less profitable firms are willing to invest in } \\
\text { injury prevention as short term benefits not exceed the } \\
\text { costs of safety. }\end{array}$ & $\begin{array}{l}\text { [25] Found an inverse relationship between prof- } \\
\text { itability and non fatal injuries with los days and } \\
\text { also with most serious occupational injuries in coal } \\
\text { mines in US. }\end{array}$ \\
\hline
\end{tabular}

Source: own based on referred studies.

\section{Materials}

Indicators used correspond to registered workers as employees who suffered or were declared an injury because of accidents or diseases related to employment. A work accident is considered all sudden and violent eventstaking place in the workplace or on the way between the worker's residence and place of work ${ }^{7}$.

Data are published by the Board of Occupational Risks (BOR), an autonomous body under the Ministry of Labor and Social Security ${ }^{8}$. The BOR publishes a yearbook with reported occupational injuries and diseases and

\footnotetext{
${ }^{7}$ In force law excludes from coverage unusual trips emerging from non-occupational issues that have not been anticipated and duly certified to the insurer.

${ }^{8}$ The goal of the BOR is the watching of fulfillment of OSH for employed population. Its main roles and objectives are: monitoring the compliance with OSH; prescription of complementary rules; controlling the operation of the Occupational Risk Insurers (ORI) and self-insured companies; imposing sanctions under the Law No. 24557 on Occupational Risks; and maintain the National Register of occupational disabilities.
} 
their incidence ratios. All figures are disaggregated by sector, province, company size, age group, sex and type of injury and cause of injury. However, disaggregated figures provided by the BOR are set beforehand. There are no available microdots allowing any kind of multivariate analysis.

According to the BOR yearbooks about 3\% of the labor contingencies are diseases of which near $60 \%$ are hearing loss and muscle injuries. This reveals that in Argentina there is virtually no record of asbestosis (asbestos poisoning), saturnism (lead poisoning), silicosis (prolonged inhalation of silica compounds), brucellosis, anthrax, psittacosis, etc. The scarce weigh of diseases in occupational health is explained not only by a limited disease catalog but also by insufficient inspections by the insurers in the workplace in order to identify risk agents $^{9}$. That underreporting plays then a role for the insurer, who can argue that worker's disease could have been contracted outside of work.

Since illness cases make up a small fraction of all cases (near 3\%) we will use the word injuries to denote both injuries and illnesses.

As BOR statistics do not publish micro data and/or sector specific variables other than injuries, we can only estimate the role of sector circumstances (business cycle and profitability) and time specific effects.

Figures for accidents and occupational diseases published by the BOR display a cyclical behavior but decreasing trend of accidents on workplaces. The rest of the occupational injuries show a rising trend since the beginning of the new regulation, particularly accidents on journeys to and from the workplace. Those trends suggest that occupational injuries not occurring in the workplace and/or diseases are not linked to business cycle, unlike the in situ accidents. Anyway this hypothesis should be checked in a multivariate analysis in Figure 1.

In Argentina the cyclical behavior of occupational accidents in workplaces comes out from the fact that during economic upwards accidents tend to increase more rapidly than employment and during downwards the absolute number of reported accidents decreases (either because there is less exposure or because under reporting) (see Figure 2 in Appendix). Although figures about registered workers do not exhibit sharp drops in the period 1997-2013, many sources agree that1998-2002 were recessive, and since 2008 the aggregate activity level stagnated specially after 2011 [33] [34].

The increasing trend in the number of insured employees even after 2008, despite signs of deterioration in economic activity, can be explained to an increase in the number of part-time employees (specially after 2010) and a decline in working hours(which increases the denominator, but not necessarily the exposure).

The BOR does not make public other sector figures, as revenues, profits or contracting conditions. There are incidence rates (per 1000 registered workers)

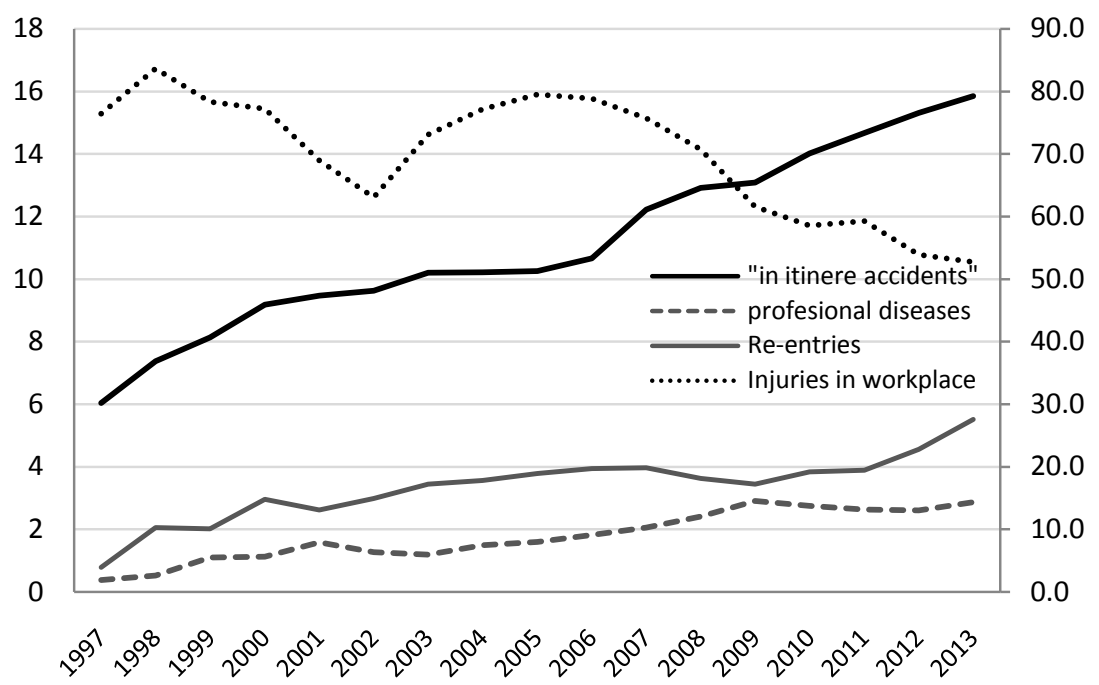

Figure 1. Argentina: occupational injuries 1997-2013. Source: own based on BOR yearbooks.

\footnotetext{
${ }^{9}$ Moreover, the ORL exempt visits periodically and present reports on risk agents in establishments with less than 6 employees. Also, routine visits are required to insurers when establishment' incidence rates exceed ones of its sector or size group and/ exceeds 3 annual injuries or 1 fatal accident per year (BOR Act 463/2009). Thus, working environments less risky than the average are not subject to sufficient controls, either by insurers or public agencies.
} 
few comparable sources of information offering data about business cycle. We use gross value added and gross production value by sector made available by the National Bureau of National Accounts (Dirección Nacional de Cuentas Nacionales). Economic variables by sector are available for the period 2004-2013, so econometric estimations restrict observations to that period.

\section{Methods}

The empirical strategy poses to estimate equations of the form:

$$
O I=f(A C T, P R O F, X)
$$

where $O I$ is the dependent variable, $A C T$ is the business cycle indicator proxied by natural log of value added, $P R O F$ is the level of profitability proxied by the revenue per worker. To estimate Equation (1) we arranged a unique dataset of 9 economic sectors with 1 digit ISIC aggregation level ${ }^{10}$ for the period 2004-2013.

Occupational injuries and $95 \%$ confidence intervals $(95 \% C I)$ for business cycle, profitability, sector and time specific effects were estimated, with the following mean:

$$
O I_{i t}=b 0_{i}+b 1 L V A_{i t}+b 2 P R O F_{i t}+\sum b_{4 t} t+N_{i t}+u_{i t}
$$

where the dependent variable, $O I$, was measured in 5 different and non-mutually exclusive ways: all reported nonfatal injuries, fatal injuries, injuries on the way to work and average duration of lost workdays. LVA denotes the activity level for each sector and year, proxied by natural log of gross value added, $P R O F$ was approximated by revenue per worker. $\beta 0$ captures sector-specific effect and $\beta 4$ year-specific effect. $N$ represents the number of insured workers. Subscripts $i$ and $t$ indicate sector and period observations, correspondingly.

For the first 3dependent variables, which register number of events recorded in sector $i$ during year $t$, as they are non negative count data we used a negative binomial distribution ${ }^{11}$. In that 3 cases we included the number of insured workers as the exposure variable ${ }^{12}$. Also, for fatal at work injuries we've considered the number of reported cases in order to get fatality rates. In the case of mean lost workdays, we followed the classical assumption of normality.

In all cases, panel data techniques were applied. Since it is not possible to capture adequately the differences across sector in worker's skill levels with these data, this fact could introduce correlation between the individual effect and the magnitude of explanatory variables, a condition not supported by a random effect model [35] ${ }^{13}$. So, the equations estimated shape the sector specific heterogeneity, $\beta 0$, as a fixed effect.

Models were estimated with Statav. 11 statistical software.

\section{Results}

Estimations for a panel of 9 one-digit level activities during 2004-2013 show that work-related injuries exhibit a counter-cyclical pattern in terms of incidence rates and a pro-cyclical relation in the average duration of lost work days (Table 5). Thus, a 1\% increase in annual value added reduce near 21 points the incidence rate of non fatal accidents at work, it also decreases almost 39\% the incidence of fatal injuries, 31\% the rate of fatality and $24 \%$ the incidence of accidents on the way to work. In contrast, the average lost days tends to increase near 59\% with each $1 \%$ increase in value added.

The negative relationship between accident rates and the business cycle can be split in two sources. The first one comes from the fact that between 2008-2013, the number of registered workers in the OSH system rose, but the labor intensity declined, which may have led to a fall in incidence of work-related injuries (Figure 3 and

\footnotetext{
${ }^{10} \mathrm{BOR}$ publishes also occupational injuries figures with 3 digit ISIC aggregation but data have so many missing values in fatal injuries that impede reliable disaggregation of injuries by severity.

${ }^{11}$ Dependent variables that represent non negative count data can also be estimated with regression models based on Poisson distribution. In fact, Poisson is a particular case of negative binomial distribution that imposes the restriction that sample mean and variance are equal (absence of overdispersion), an assumption not frequent in accidents analysis specially due to unobservable heterogeneity [36].

${ }^{12} \mathrm{As}$ explained above, the headcount of registered workers is worse than working hours or full-time workers as indicator of exposure, but it is the only proxy available.

${ }^{13} \mathrm{~A}$ random effect (RE) model can effectively capture regressors' variations within each sector and between sectors affecting the dependent variable. The estimation method is based on Generalized Least Squares. The RE model produces consistent estimators if $\beta 0$ is uncorrelated with predictors. Conversely, the fixed model allows correlation between $\beta 0$ and explanatory variables so, conditional on the predictors are exogenous and/or uncorrelated with the classical error term $u_{i t}$, its results are consistent.
} 
Table 5. Fixed effect model estimates. incidence rate ratios.

\begin{tabular}{|c|c|c|c|c|c|}
\hline Variables & nonfatal & fatal & fatal $^{\prime}$ & in itinere & Avg lost days \\
\hline \multirow[t]{2}{*}{ Log of value added } & $0.887^{* * *}$ & $0.611^{* * *}$ & $0.690^{* * *}$ & $0.756^{* * *}$ & $1.588^{* * *}$ \\
\hline & $(0.00194)$ & $(0.00497)$ & $(0.00557)$ & $(0.00146)$ & $(0.0525)$ \\
\hline \multirow[t]{2}{*}{ Revenue per worker } & 0.919 & $3.472^{* * *}$ & $3.470^{* * *}$ & $1.459^{* * *}$ & -1.9999 \\
\hline & $(0.0878)$ & (1.643) & $(1.637)$ & $(0.153)$ & $(2.6217)$ \\
\hline \multirow[t]{2}{*}{ Sector $=2$, mining } & $0.676^{* * *}$ & $0.314^{* * *}$ & $0.495^{*}$ & $0.456^{* * *}$ & 1.549 \\
\hline & $(0.0501)$ & $(0.118)$ & $(0.185)$ & $(0.0347)$ & $(1.813)$ \\
\hline \multirow[t]{2}{*}{ Sector $=3$, manufacturing } & $1.177^{* * *}$ & $0.540^{* * *}$ & $0.463^{* * *}$ & $2.727^{* * *}$ & $-7.988^{* * *}$ \\
\hline & $(0.0327)$ & $(0.0413)$ & $(0.0349)$ & $(0.0561)$ & $(0.72515)$ \\
\hline \multirow[t]{2}{*}{ Sector $=4$, electricity, gas $\&$ water sup } & $0.415^{* * *}$ & $0.351^{* * * *}$ & 0.856 & $0.651^{* * * *}$ & -0.8018 \\
\hline & $(0.0112)$ & $(0.0410)$ & $(0.0995)$ & $(0.0151)$ & $(0.96404)$ \\
\hline \multirow[t]{2}{*}{ Sector $=5$, Construction } & $1.414^{* * *}$ & $1.106^{*}$ & $0.777^{* * *}$ & $1.882^{* * *}$ & $-6.883^{* * * *}$ \\
\hline & $(0.0361)$ & $(0.0665)$ & $(0.0459)$ & $(0.0335)$ & $(0.58631)$ \\
\hline \multirow[t]{2}{*}{ Sector $=6$, retailing } & $0.667^{* * *}$ & $0.380^{* * * *}$ & $0.564^{* * *}$ & $2.312^{* * *}$ & $-9.964^{* * *}$ \\
\hline & $(0.0192)$ & $(0.0339)$ & $(0.0498)$ & $(0.0507)$ & $(0.6886)$ \\
\hline \multirow[t]{2}{*}{ Sector $=7$, transport } & $0.747^{* * *}$ & 1.059 & $1.419^{* * *}$ & $1.949^{* * *}$ & $-2.411^{* * *}$ \\
\hline & $(0.0192)$ & $(0.0619)$ & $(0.0811)$ & $(0.0343)$ & $(0.6341)$ \\
\hline \multirow[t]{2}{*}{ Sector $=8$, financial SERVICES } & $0.498^{* * *}$ & $0.389^{* * *}$ & $0.775^{* * *}$ & $2.298^{* * *}$ & $-7.865^{* * *}$ \\
\hline & $(0.0135)$ & $(0.0313)$ & $(0.0615)$ & $(0.0448)$ & $(0.6882)$ \\
\hline \multirow[t]{2}{*}{ Sector $=9$, social services } & $0.431^{* * *}$ & $0.277^{* * *}$ & $0.633^{* * *}$ & $1.792^{* * *}$ & $-2.038^{* *}$ \\
\hline & $(0.0143)$ & $(0.0328)$ & $(0.0743)$ & $(0.0514)$ & $(0.8570)$ \\
\hline \multirow[t]{2}{*}{ Year $=2005$} & 1.029 & 0.938 & 0.912 & $1.035^{*}$ & 0.135 \\
\hline & $(0.0278)$ & $(0.0630)$ & $(0.0598)$ & $(0.0198)$ & $(0.6528)$ \\
\hline \multirow[t]{2}{*}{ Year $=2006$} & 1.044 & 0.999 & 0.964 & $1.112^{* * * *}$ & $2.488^{* * * *}$ \\
\hline & $(0.0283)$ & $(0.0659)$ & $(0.0620)$ & $(0.0212)$ & $(0.6178)$ \\
\hline \multirow[t]{2}{*}{ Year $=2007$} & 1.009 & 0.959 & 0.955 & $1.243^{* * * *}$ & $4.588^{* * *}$ \\
\hline & $(0.0275)$ & $(0.0635)$ & $(0.0616)$ & $(0.0237)$ & $(06185)$ \\
\hline \multirow[t]{2}{*}{ Year $=2008$} & $0.954^{*}$ & $0.870^{* *}$ & 0.916 & $1.288^{* * * *}$ & $5.233^{* * *}$ \\
\hline & $(0.0264)$ & $(0.0589)$ & $(0.0607)$ & $(0.0248)$ & $(0.5072)$ \\
\hline \multirow[t]{2}{*}{ Year $=2009$} & $0.850^{* * *}$ & $0.737^{* * *}$ & $0.862^{* *}$ & $1.282^{* * *}$ & $4.916^{* * *}$ \\
\hline & $(0.0235)$ & $(0.0517)$ & $(0.0591)$ & $(0.0247)$ & $(0.5130)$ \\
\hline \multirow[t]{2}{*}{ Year $=2010$} & $0.824^{* * *}$ & $0.764^{* * *}$ & 0.922 & $1.396^{* * *}$ & $5.754^{* * *}$ \\
\hline & $(0.0226)$ & $(0.0524)$ & $(0.0619)$ & $(0.0266)$ & $(0.5072)$ \\
\hline \multirow[t]{2}{*}{ Year $=2011$} & $0.829^{* * *}$ & $0.839^{* * *}$ & 1.001 & $1.482^{* * *}$ & $7.540^{* * *}$ \\
\hline & $(0.0228)$ & $(0.0563)$ & $(0.0655)$ & $(0.0282)$ & $(0.5050)$ \\
\hline \multirow[t]{2}{*}{ Year $=2012$} & $0.771^{* * *}$ & $0.837^{* * *}$ & 1.076 & $1.627^{* * *}$ & $9.363^{* * *}$ \\
\hline & $(0.0214)$ & $(0.0560)$ & $(0.0705)$ & $(0.0310)$ & $(0.6740)$ \\
\hline \multirow[t]{2}{*}{ Year $=2013$} & $0.776^{* * * *}$ & $0.678^{* * * *}$ & $0.876^{*}$ & $1.769^{* * * *}$ & $10.629^{* * * *}$ \\
\hline & $(0.0216)$ & $(0.0474)$ & $(0.0601)$ & $(0.0335)$ & $(0.7816)$ \\
\hline \multirow[t]{2}{*}{ Alpha// } & $0.00316^{* * *}$ & $0.00220^{* * *}$ & $0.00153^{* * *}$ & $0.00124^{* * *}$ & - \\
\hline & $(0.000480)$ & $(0.00261)$ & $(0.00244)$ & $(0.000237)$ & - \\
\hline No. observations, $\mathrm{N} \times \mathrm{T}$ & 90 & 90 & 90 & 90 & 90 \\
\hline
\end{tabular}

/Exposure indicator $=$ number of injuries. //Alpha is the dispersion parameter. If the dispersion parameter equals 0 , the model reduces to the simpler Poisson model. If is greater than 0 , the data are overdispersed and are better estimated using a negative binomial model. Standard error in parentheses. ${ }^{* * *} P<0.01,{ }^{* *} P<0.05,{ }^{*} P<0.1$. Source: own calculations. 
Figure 4 in Appendix) ${ }^{14}$. In order to capture potential slow down in labor intensity (emerging from suspensions of shifts, increases of part-time jobs, etc.), a dummy variable that takes unit value from 2008 onwards interacting with the log added value was included. The coefficient of the interaction term coefficient was significant and negative over non-fatal and fatal incidence rates, indicating that occupational injuries at work decreased even more since 2008. It also happens to be significant but positive over the incidence of on-road occupational accidents (see estimations results in Table A1 in Appendix).The second source comes from the fact that even controlling for labor intensity (through interaction between value added and the dummy variable) the association between growth and at-work accident rates is still negative. These findings can be interpreted as a sign of cost-contention supremacy (i.e. workers underreporting accidents at work for fear of job loss; insurers disclaiming accidents reported as a cost' contention strategy) over the worker's motives (pro-cyclical). Actually, the upturn in Argentina's employment figures between 2004-2007was based on high rates of informal and temporary hiring of workers which could induce under reporting occupational injuries.

In turn, fatal occupational accidents and fatality rates increased significantly in more profitable sectors. Also, profitability has raised near $46 \%$ the rate of in itinere injuries. There's a trade off, thus, between firm profitability and fatal occupational occurrence and work-related mortality rates.

As agriculture was taken as base category, sector-specific coefficients indicate that construction has the highest incidence rates in non fatal and fatal occupational injuries at work. Transport and agriculture activities exhibit the highest fatality rates (deaths per injured workers). As expected, agriculture has the lowest incidence rates for traffic-related injuries as workers live close to their jobs and/or rural roads are safer than urban environments. On the other hand, work-related accidents have more lost work days in agriculture. Retailing, manufacturing, financial services and construction exhibit considerable less work days' losses by injuries at work. This result can be related to less severity in injuries (retailing and financial services have relatively low fatal working injuries rates) but also to establishment's pressures to workers return to work if the job is highly specialized (manufacturing, construction).

\section{Discussion}

[27] Found a counter-cyclical relation in some sectors (where small sized firms predominate) and groups of workers (females); in sectors reporting the highest injuries rates, a pro-cyclical relation between accidents and business cycle prevails. Local indicators do not allow us to evaluate sparately the relationship between business cycle and occupational injuries by sector (time series with available data on value added and at work accidents are not long enough to apply powerful econometric tools). Nevertheless, as the structure of employment in Argentina rests in sectors with low incidence rates of occupational accidents (social services, retailing), that explains an imbalance in favor of countercyclical forces of occupational accidents.

We also find symptoms suggesting that the decreasing trends in occupational injuries, especially after 2008 may be related to drops in quality of employment. The fall in the number of accidents simultaneous with increases of the insured workers alert about a possible deterioration of labor conditions that either reduces incentives to declare accidents or directly diminishes them as exposure levels are lower. For that reason, as the rising of registered workers is not always correlated with increasing activity levels, BOR statistics should report better indicators of exposure (hours worked, full-time employees).

In turn, while the relation between business cycle and occupational injuries may be different between activities, we do not register significant deviations from the counter cyclical pattern (see Figure 5 in Appendix). At most, some sectors (Agriculture) display a weak relation between growth and injuries at work.

The negative relation between fatal and traffic - related occupational injuries rates and profitability contrasts with the findings reported in [25] for US coal mines. In Argentina and probably in less developed countries, OSH practices seem to be at odds with business success. Or, inversely, employers' profits need less safe labor conditions to reach satisfactory levels. If that hypothesis holds, this could imply some sort of endogeneity between occupational safety and firms' profit rate.

We found no evidence that reforms in the OSH system have had an impact on working accidents' rates. A similar conclusion is found by [37] and [38] in Spain, who found that declining occupational trends seem to be related with changes in productive structures and labor market dynamics. Our time span is still short in order to

\footnotetext{
${ }^{14}$ In fact, estimations show a declining rate of non fatal and fatal injuries since 2008. In contrast, the increasing trends of occupational injuries at road and average lost days were present for the whole period.
} 
assert significant changes in productive structure ${ }^{15}$. Nevertheless, during 2004-2013 economic growth and investment concentrated mainly in agriculture, mining and construction sectors [39], which tend to exhibit high occupational injuries rates, suggesting that labor market conditions may explain main variations in working accidents rates. In fact, during the 1990s major labor regulation took place, which shaped more flexible conditions for hiring and firing workers giving raise an environment where employment is less stable than past decades. As cited before, some authors interpret that changes in labor market regulations may induce under reporting occupational injuries. Also, the administration of workers' compensation emerging from occupational injuries by private insurers constitutes encourages itself underreporting by insurers' disclaim of injuries as work-related.

\section{Final Remarks}

Argentina, as many under developed countries, exhibits relative higher rates of occupational injuries and less days lost by temporary incapacity. Since the approval of a new law regulating occupational risks in workplaces in 1996, figures showed mixed results. At work accidents rates decreased moderately, fatal injuries decrease in most risky activities, average working days lost by accidents increase and injuries occurring on the way to work have experienced a sustained growth. After many claims questioning the ignorance of constitutional rights by ORL, several reforms were introduced in 2012. Those reforms are not aimed at improving the prevention, but also reducing litigation in occupational injuries. While the legal framework facilitates action for injured workers as it establishes compensation fees, the management by private profit-oriented insurers also hinders the worker from a fair and full compensation. Moreover, the civil liability system may grant full compensation to injured workers but requires the victim to prove the damage and its causal link with working activities [40]. Therefore, full civil compensation will not necessarily result in higher benefits established by law.

Argentina's public agencies lack of analyses trying to connect occupational injuries or their evolution with economic environment or changes in labor safety system. Our estimations display three main caveats: first, a negative relation between growth and occupational injuries; second, a positive relation between profits and fatal labor accidents and thirdly, a sustained growing trend in occupational traffic injuries.

The counter cyclical relation between business cycle and occupational injuries observed in Argentina needs to be studied with more detail; if employment increases with also simultaneous worsening of jobs' quality, occupational injuries rates may decline hiding failures in the protection of injured and disabled workers. Also, attention must be paid to most profitable activities (in terms of revenue per worker) as they exhibit higher fatality rates.

It will be extremely useful to complete the recording system in order to isolate the effects of different kind of predictors of occupational accidents and diseases (sociodemographicas age, gender, education, experience; environmental like type of contract, salary, size of establishment, provision of adequate tools and safe places, duration of the working day, exposure to toxic and unhealthy substances; and behavioral as alcohol consumption, smoking, sleep disorders, work stress, job satisfaction, etc.). While behavior-related variables do require more effort registration and may be subject to greater error, the first 2 (sociodemographic and environmental) are considerably easier to gather and will help to discriminate the weight of environmental factors on pre-existing conditions in the occupational health.

Public agencies and researchers should examine forces preventing the registration of occupational injuries and diseases more closely to better understand trends in OSH.

\section{References}

[1] ILO (2009) Facts on Safety and Health at Work.

[2] CTA (2007) Los obstáculos al acceso a la justicia en materia de accidentes y enfermedades laborales. http://archivo.cta.org.ar/IMG/pdf/Dictamen_CTA_sobre_la_ORL_-_Comision_Interamericana_de_Derechos_Human os-2.pdf

[3] Ramirez, L.E. (2010) Riesgos del Trabajo. Manual Práctico, Fondo de Cultura Económica, Buenos Aires.

[4] Ruser, J. and Butler, R. (2010) The Economics of Occupational Safety and Health. Foundations \& Trends in Microeconomics, 5, 301-354. http://dx.doi.org/10.1561/0700000036

[5] Rand, B. and Worrall, J. (1991) Claims Reporting and Risk Bearing Moral Hazard in Workers’ Compensation. Journal of Risk and Insurance, 58, 191-204.

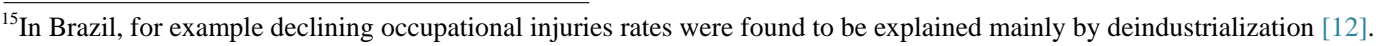


[6] Giuffrida, A., Fiunes, R. and Savedoff, W. (2002) Occupational Risks in Latin America and the Caribbean: Economic and Health Dimensions. Health Policy \& Planning, 17, 235-246. http://dx.doi.org/10.1093/heapol/17.3.235

[7] Gosh, A.K., Bhattacherjee, A. and Chau, N. (2004) Relationships of Working Conditions and Individual Characteristics to Occupational Injuries: a Case-Control Study in Coal Miners. Journal of Occupational Health, 46, 470-478. http://dx.doi.org/10.1539/joh.46.470

[8] Molla, G.A., Salgedo, W.B. and Lemu, Y. (2015) Prevalence and Determinants of Work Related Injuries among Small and Medium Scale Industry Workers in Bahir Dar Town, North West Ethiopia. Annals of Agricultural and Environmental Medicine, 27, 12. http://dx.doi.org/10.1186/s40557-015-0062-3

[9] Li, C.Y. (2001) Job Stress and Dissatisfaction in Association with Non-Fatal Injuries on the Job in a Cross-Sectional Sample of Petrochemical Workers. Occupational Medicine, 51, 50-55. http://dx.doi.org/10.1093/occmed/51.1.50

[10] Guadalupe, M. (2002) The Hidden Costs of Fixed Term Contracts: The Impact on Work Accidents. Center for Economic Performance.

http://eprints.lse.ac.uk/20064/1/The_Hidden_Costs_of_Fixed_Term_Contracts_the_Impact_On_Work_Accidents.pdf

[11] García, I. and Montuenga, V.M. (2004) Determinantes de la siniestralidad laboral. FUNDEAR. Documento de Trabajo No. 8.

[12] Wunsch Filho, V. (1999) Reestruturação produtiva e acidentes de trabalho no Brasil: Estrutura e tendência. Cadernos de Saúde Pública, 15, 41-51. http://dx.doi.org/10.1590/S0102-311X1999000100005

[13] Barreto, S.M., Swerdlow, A.J., Smith, P.G., Higgins, C.D. and Andrade, A. (1996) Mortality from Injuries and Other Causes in a Cohort of 21,800 Brazilian Steel Workers. Occupational and Environmental Medicine, 53, 343-350. http://dx.doi.org/10.1136/oem.53.5.343

[14] Santana, V., Nobre, L. and Waldvogel, B. (2005) Acidentes de trabalho no Brasil entre 1994 e 2004: Uma revisão. Ciência e Saúde Coletiva, 10, 841-855. http://dx.doi.org/10.1590/S1413-81232005000400009

[15] Moradinazar, M., Kurd, N., Farhadi, R., Amee, V. and Najafi, F. (2013) Epidemiology of Work-Related Injuries among Construction Workers of Ilam (Western Iran) during 2006-2009. Iranian Red Crescent Medical Journal, 15, e8011. http://dx.doi.org/10.5812/ircmj.8011

[16] Perez Chada, D., Videla, A.J., O’Flaherty, M.E., Palermo, P., Meoni, J., Sarchi, M.I., Khoury, M. and Duran-Cantolla, J. (2005) Sleep Habits and Accident Risk among Truck Drivers: A Cross-Sectional Study in Argentina. Sleep, 28, 1103-1108.

[17] Martinez, D., Collazo, M. and Liss, M. (2009) Dimensiones del trabajo docente: Una propuesta de abordaje del malestar y el sufrimiento psíquico de los docentes en la Argentina. Educação \& Sociedade, 30, 389-408. http://dx.doi.org/10.1590/S0101-73302009000200005

[18] Molineri, A., Signorini, M., Perez, L. and Tarabla, H. (2013) Zoonoses in Rural Veterinarians in the Central Region of Argentina. Australian Journal of Rural Health, 21, 285-290. http://dx.doi.org/10.1111/ajr.12054

[19] Kohen, J. (1997) Nuevas relaciones laborales y salud de los trabajadores en Argentina. Desafíos y perspectivas para la investigación. Cadernos de Saude Pública, 13, S47-S57. http://dx.doi.org/10.1590/S0102-311X1997000600005

[20] Hamalainen, P., Takala, J. and Saarela, K. (2006) Global Estimates of Occupational Accidents. Safety Science, 44, 137-156. http://www.ilo.org/wcmsp5/groups/public/@dgreports/@dcomm/documents/publication/wcms_105146.pdf http://dx.doi.org/10.1016/j.ssci.2005.08.017

[21] Aderaw, Z., Engdar, D. and Tadesse, T. (2011) Determinants of Occupational Injury: A Case Control Study among Textile Factory Workers in Amhara Regional State, Ethiopia. Journal of Tropical Medicine, 2011, Article ID: 657275. http://dx.doi.org/10.1155/2011/657275

[22] Min, K.B., Park, S.G., Song, J.S., Yi, K.H., Jang, T.W. and Min, J.Y. (2013) Subcontractors and Increased Risk for Work-Related Diseases and Absenteeism. American Journal of Industrial Medicine, 56, 1296-306. http://dx.doi.org/10.1002/ajim.22219

[23] Davies, R., Jones, P. and Nuñez, I. (2009) The Impact of the Business Cycle on Occupational Injuries in the UK. Social Science \& Medicine, 69, 178-182. http://dx.doi.org/10.1016/j.socscimed.2009.04.033

[24] Mouza, A.M. and Targoutzidis, A. (2012) The Impact of the Economic Cycle on Fatal Injuries. The Case of UK 1971-2007. Quality \& Quantity, 46, 1917-1929. http://dx.doi.org/10.1007/s11135-012-9700-9

[25] Asfaw, A., Mark, C. and Pana-Cryan, R. (2012) Profitability and Occupational Injuries in U.S. Underground Coal Mines. Accident Analysis \& Prevention, 50, 778-786. http://dx.doi.org/10.1016/j.aap.2012.07.002

[26] Kossoris, M.D. (1938) Industrial Injuries and the Business Cycle. Monthly Labour Review, 46, 579-594.

[27] Davies, R. and Jones, P. (2005) Trends and Context to Rates of Workplace Injury. Research Report 386, Health and Safety Executive, Liverpool. 
[28] Terres de Ercilla, F., Mondelo, P., Casado, A. and Vilella, E. (2004) Economic Fluctuations Affecting Occupational Safety. The Spanish Case. Occupational Ergonomics, 4, 211-228.

[29] Boone, J. and van Ours, J.C. (2006) Are Recessions Good for Health? Journal of Health Economics, 25, $1069-1093$. http://dx.doi.org/10.1016/j.jhealeco.2006.03.002

[30] Azaroff, L., Lax, M., Levenstein, C. and Wegman, D. (2004) Wounding the Messenger: The New Economy Makes Occupational Health Indicators Too Good to Be True. International Journal of Health Services, 34, 271-303. http://dx.doi.org/10.2190/4H2X-XD53-GK0J-91NQ

[31] Saloniemi, A. and Oksanen, H. (1998) Accidents and Fatal Accidents—Some Paradoxes. Safety Science, 29, 59-66. http://dx.doi.org/10.1016/S0925-7535(98)00016-2

[32] Nichols, N. (1991) Industrial Injuries in British Manufacturing Industry and Cyclical Effects: Continuities and Discontinuities in Industrial Injury Research. The Sociological Review, 39, 131-139. http://dx.doi.org/10.1111/j.1467-954X.1991.tb02972.x

[33] Talvi, E. (2014) Macroeconomic Vulnerabilities in an Uncertain World: One Region, Three Latin Americas. Brookings Global/CERES.

http://www.brookings.edu/ /media/research/files/reports/2014/09/latin-america-macroeconomic-outlook-talvi/2014esplamacro-web.pdf

[34] Zack, G. (2015) El papel de las políticas públicas en los períodos de crecimiento y desaceleración en América Latina. Documento de Trabajo IELAT No. 72. http://www.ielat.es/inicio/repositorio/DT_72_Guido_Zack_Web.pdf

[35] Baltagi, B. (2013) Econometric Analysis of Panel Data. 5th Edition, Wiley, Chichester.

[36] Cameron, C. and Trivedi, P. (2013) Econometric Analysis of Count Data. 2nd Edition, Cambridge University Press, Cambridge, MA.

[37] Benavides, F.G., García, A.M., Lopez Ruiz, M., Gil, J., Boix, P., Martinez, J.M. and Rodrigo, F. (2011) Effectiveness of Occupational Injury Prevention Policies in Spain. Public Health Reports, 124, 180-187.

[38] Santamaria, N., Catot, N. and Benavides, F. (2006) Time Trends in Fatal Traumatic Occupational Injuries in Spain 1992-2002. Gaceta Sanitaria, 20, 280-286.

[39] Bezchinsky, G., Dinenzon, M., Giussani, L., Caino, O., López, B. and Amiel, S. (2007) Inversión extranjera directa en la Argentina. Crisis, reestructuración y nuevas tendencias después de la convertibilidad. In: Kosacoff, B., Ed., Crisis, recuperación y nuevos dilemas. La economíaargentina, 2002-2007, Cepal, Buenos Aires, 149-187.

[40] Suarez, C. (2013) Responsabilidad civil por accidentes de trabajo Ley 26773. García Alonso, Buenos Aires, 304 p. 


\section{Sources of Information}

Supreme Court of Justice, Castillo, Angel Santos c/Cerámica Alberdi SA, judgement 7th Sep. 2004.

Supreme Court of Justice, Aquino Isacio c/Cargo Servicios Industriales SA s/Accidentes ley 9688, judgement 21 Sep. 2004.

Supreme Court of Justice, Milone, Juan Antonio c/Asociart SA ART s/Accidente ley 9688, judgement 26 Oct. 2004.

Supreme Court of Justice, Llosco Raul c/Irmi SA y otra, judgement 12 Jun. 2007.

National Laws No. 24557\&26773.

Decrees No. 170/1996; 334/1996; 658/1996; 410/2001; 1167/2003; 1694/2009; 472/2014.

Award No. 156/1996.

ECLAC (Econ Comission for Latin America \& Caribean); 2013 Statistical Yearbook; available at: http://interwp.cepal.org/anuario_estadistico/anuario_2013/es/index.asp

\section{Appendix}

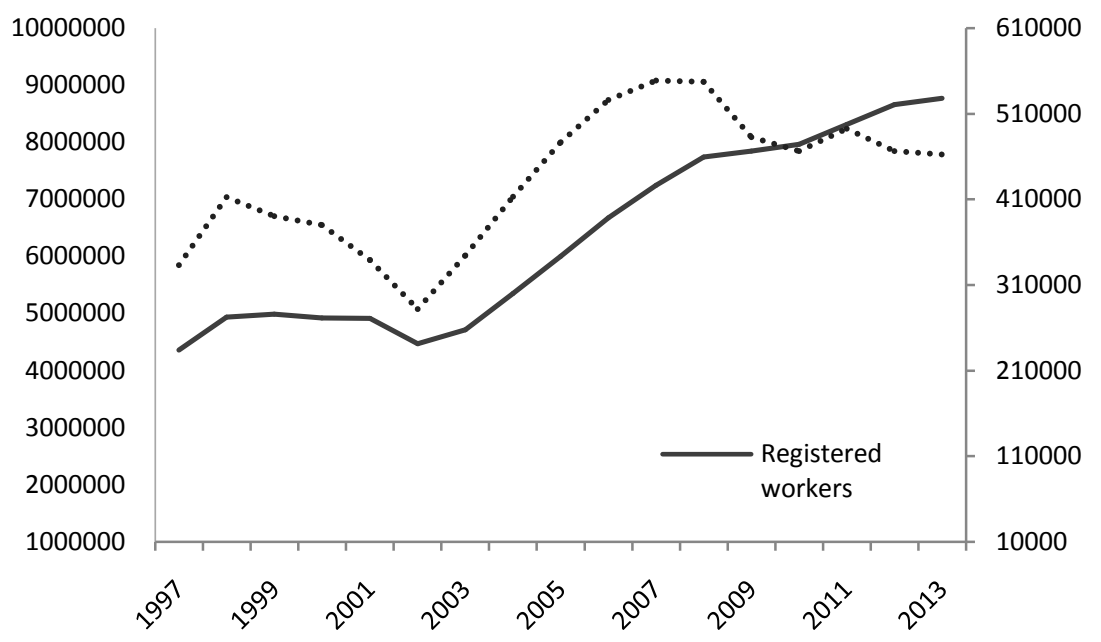

Figure 2. Injuries at work and registered workers. Totals. 1997-2013.

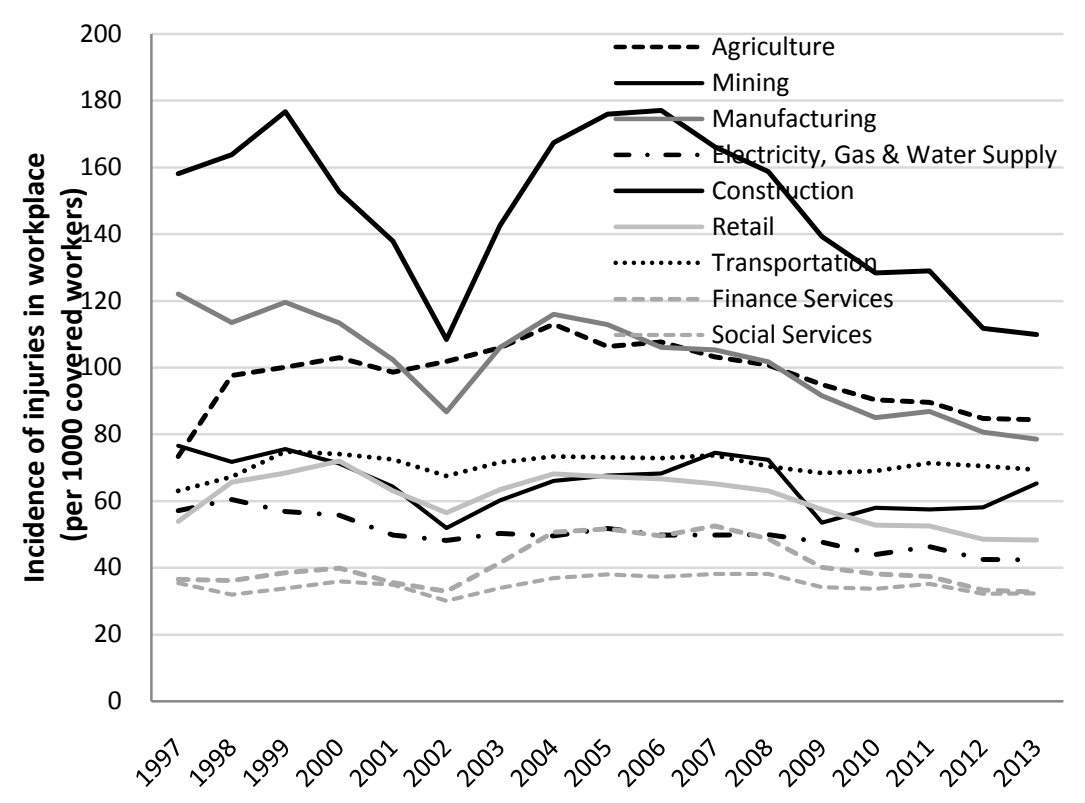

Figure 3. Injuries at work. Incidence rates by sector 1997-2013. 
V. Viego, N. Sagui

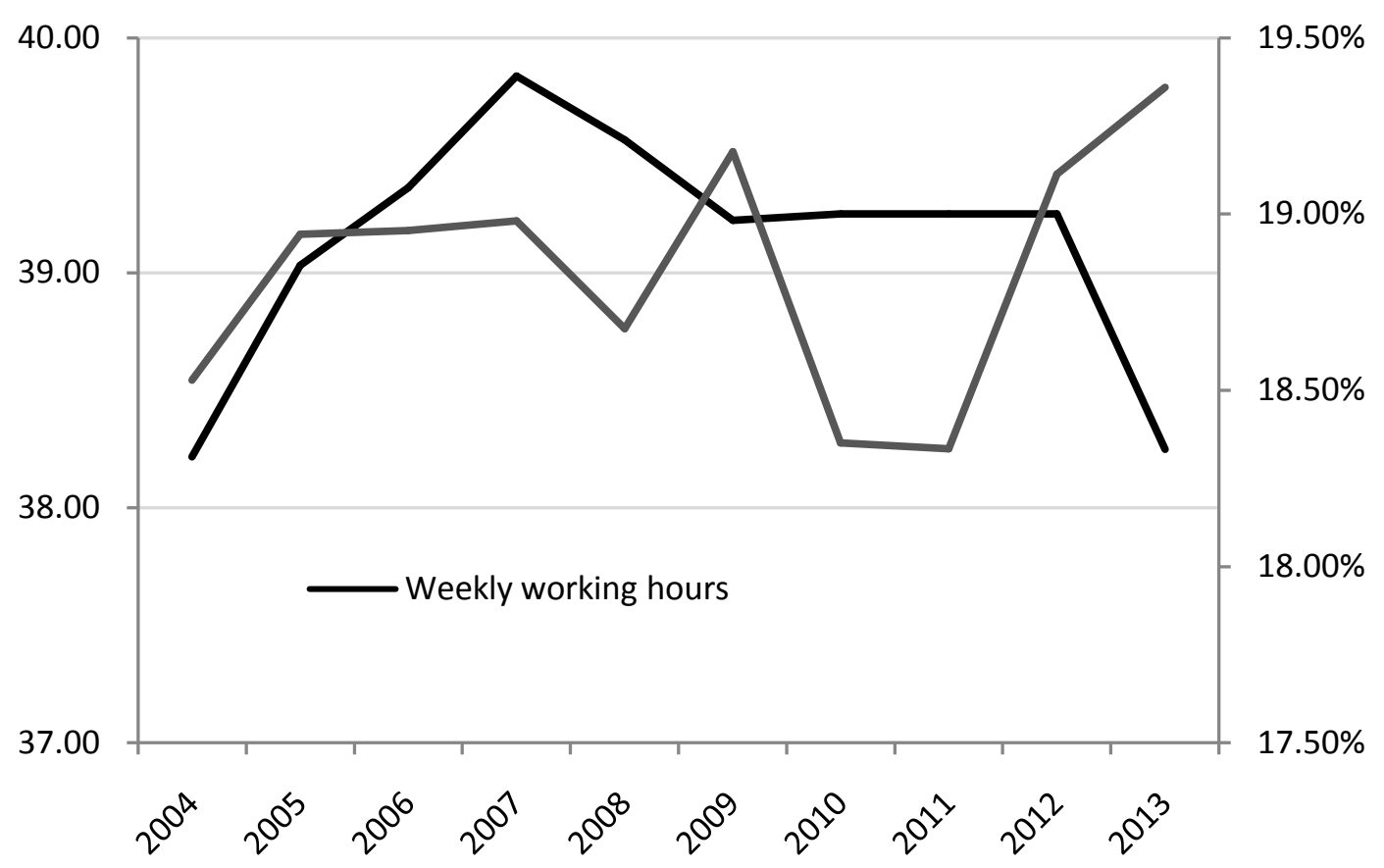

Figure 4. Working intensity 2004-2013.

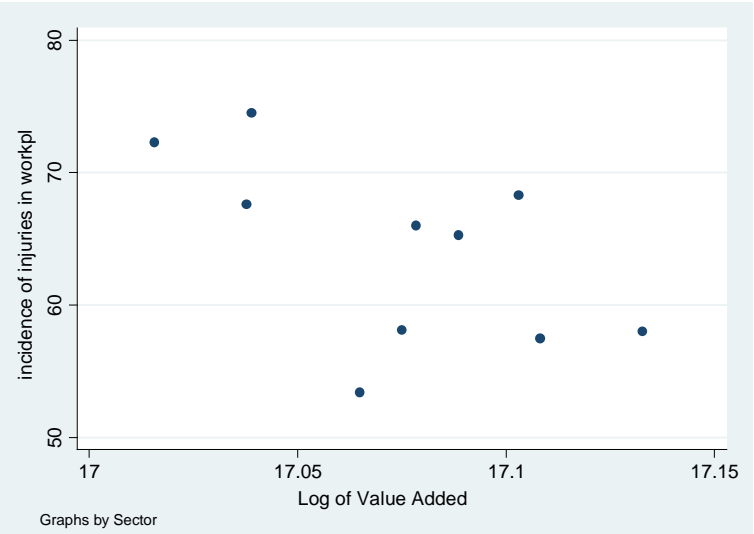

(a)

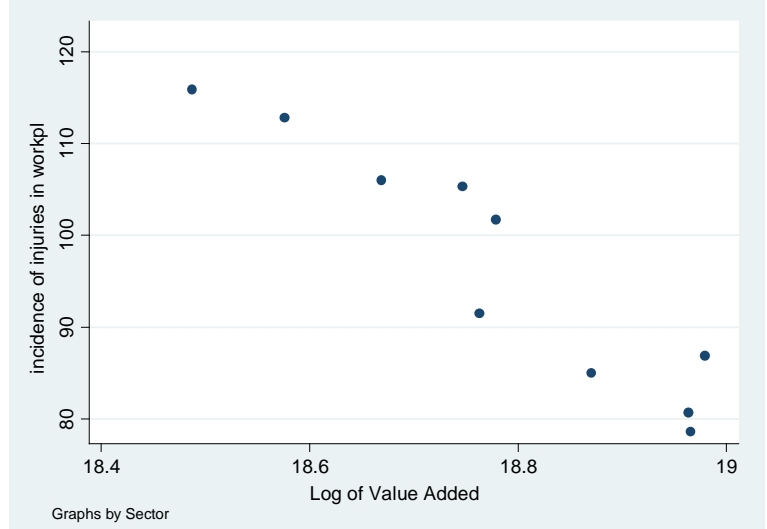

(c)

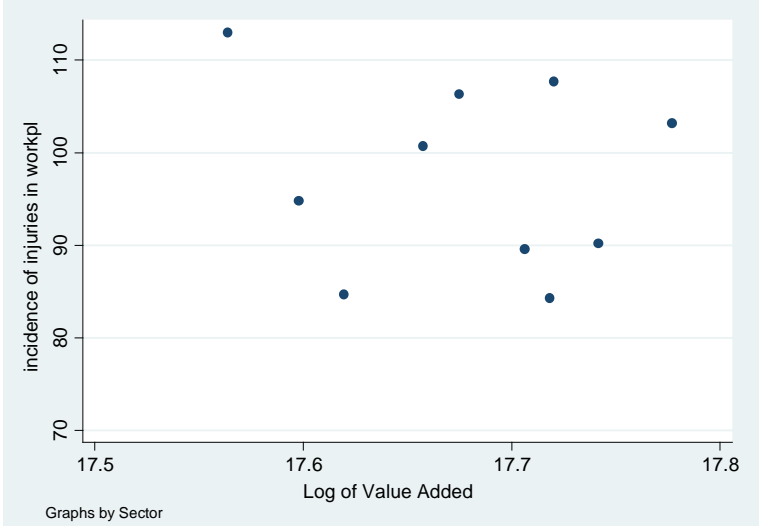

(b)

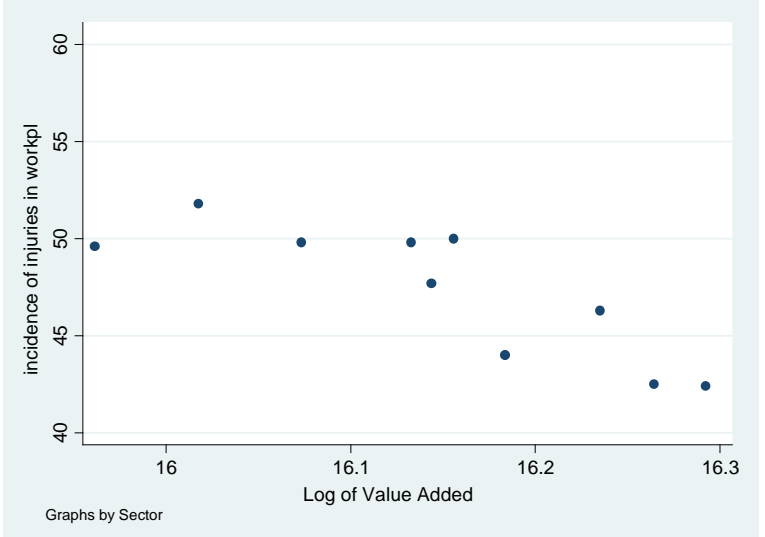

(d) 


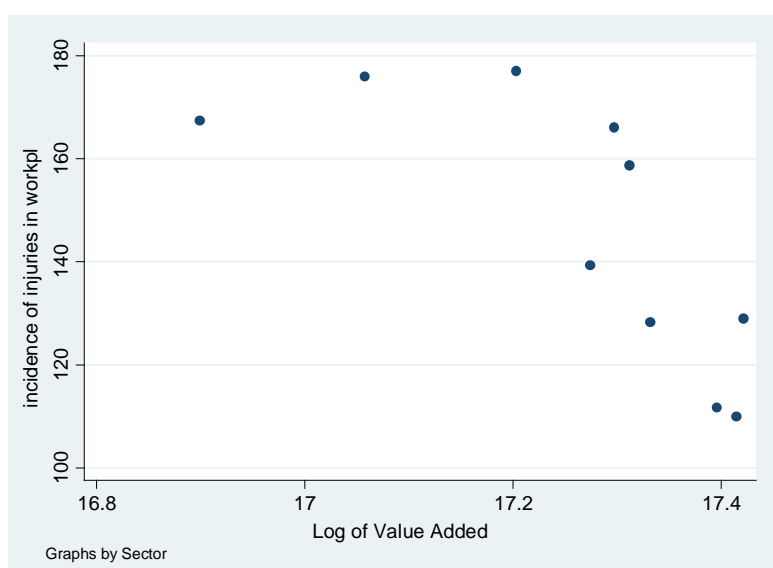

(e)

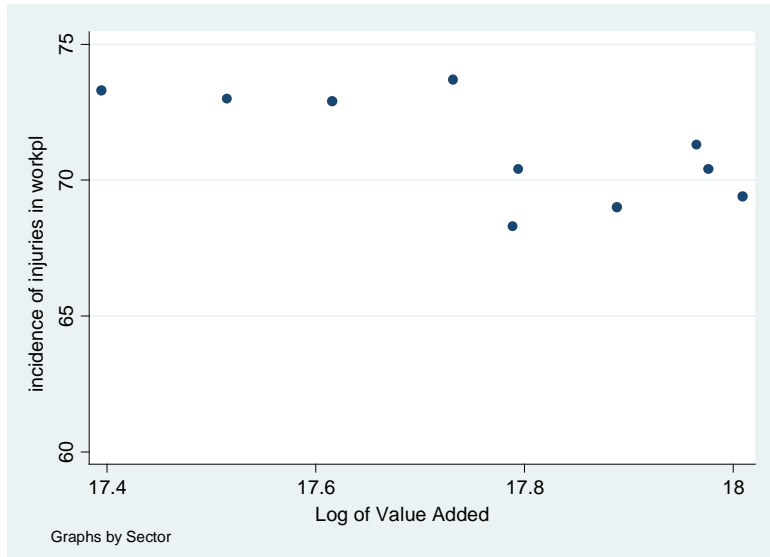

(g)

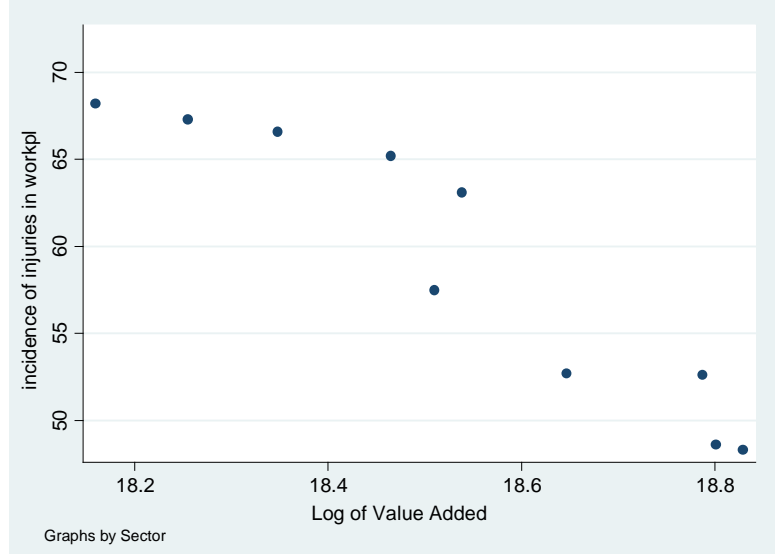

(f)

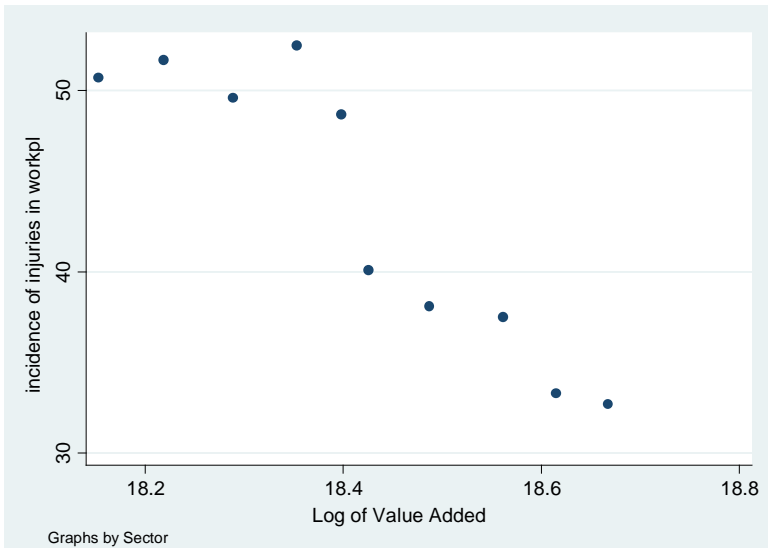

(h)

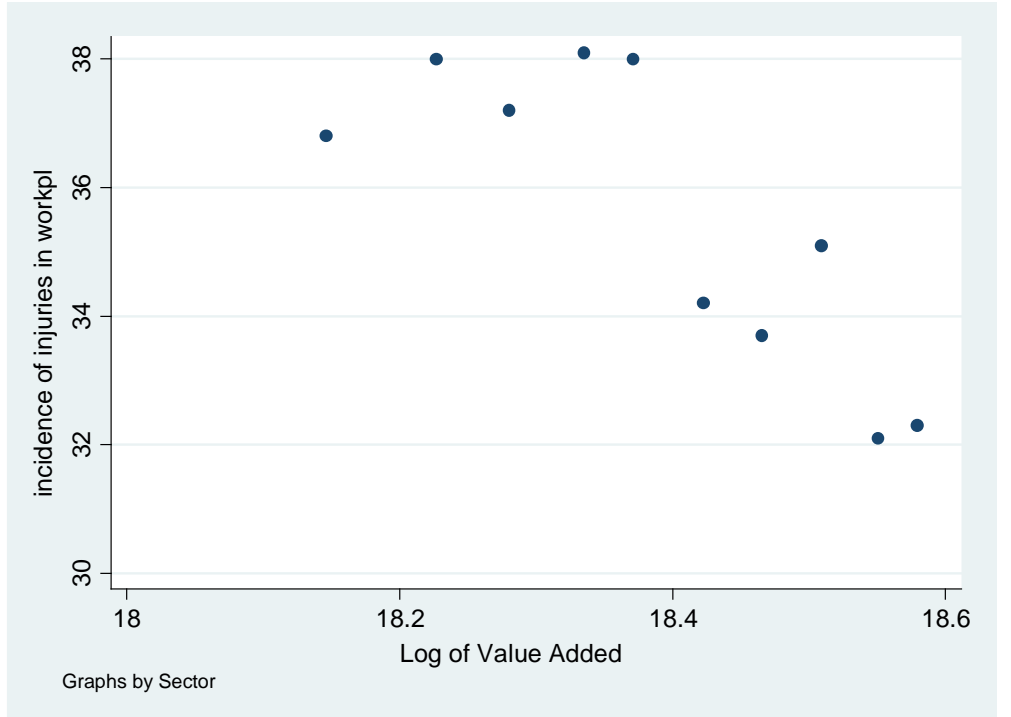

(i)

Figure 5. Relation between business cycle and rate of injuries at work, by sector. (a) Agriculture; (b) Mining; (c) Manufacturing; (d) Electricity, Gas \& Water Supply; (e) Construction; (f) Retail; (g) Transport; (h) Financial services; (i) Social Services. 
Table A1. Fixed effect model estimates with dummy indicator. Incidence rate ratios.

\begin{tabular}{|c|c|c|c|c|c|}
\hline VARIABLES & nonfatal & fatal & fatal $^{\prime}$ & in itinere & Avg lost days \\
\hline \multirow[t]{2}{*}{ Log of value added } & $0.743^{* * *}$ & $0.763^{*}$ & 0.941 & $1.786^{* * *}$ & $14.54^{* * *}$ \\
\hline & $(0.0697)$ & $(0.121)$ & $(0.132)$ & $(0.181)$ & $(2.806)$ \\
\hline \multirow[t]{2}{*}{ Log of value added $\times$ D2008 ${ }^{*}$} & $0.991^{* * *}$ & $0.986^{* * *}$ & $0.996^{* *}$ & $1.007^{* * *}$ & $0.164^{* * *}$ \\
\hline & $(0.00123)$ & $(0.00189)$ & $(0.00185)$ & $(0.00146)$ & $(0.0472)$ \\
\hline \multirow[t]{2}{*}{ Revenue per worker } & 1.011 & 2.852 & 3.456 & 0.830 & $-11.80^{* * *}$ \\
\hline & $(0.111)$ & (2.188) & $(2.737)$ & $(0.176)$ & (3.779) \\
\hline \multirow[t]{2}{*}{ Sector $=2$, mining } & $0.564^{* * *}$ & 0.414 & 0.597 & 1.152 & $16.48^{* * * *}$ \\
\hline & $(0.0674)$ & $(0.248)$ & $(0.381)$ & $(0.239)$ & $(4.443)$ \\
\hline \multirow[t]{2}{*}{ Sector $=3$, manufacturing } & $1.424^{* * *}$ & $0.438^{* * *}$ & $0.331^{* * *}$ & 1.122 & $-21.20^{* * *}$ \\
\hline & $(0.142)$ & $(0.0807)$ & $(0.0509)$ & $(0.115)$ & $(2.851)$ \\
\hline \multirow[t]{2}{*}{$\begin{aligned} \text { Sector }= & 4 \text {, electricity, gas \& } \\
& \text { water sup }\end{aligned}$} & $0.310^{* * *}$ & $0.497^{* *}$ & 1.376 & $2.565^{* * *}$ & $20.05^{* * *}$ \\
\hline & $(0.0469)$ & $(0.150)$ & $(0.394)$ & $(0.461)$ & (5.031) \\
\hline \multirow[t]{2}{*}{ Sector $=5$, construction } & $1.322^{* * *}$ & $1.198^{*}$ & 0.884 & $2.592^{* * *}$ & -2.060 \\
\hline & $(0.0810)$ & $(0.113)$ & $(0.0847)$ & $(0.176)$ & (1.986) \\
\hline \multirow[t]{2}{*}{ Sector $=6$, retailing } & $0.790^{* * *}$ & $0.310^{* * * *}$ & $0.435^{* * *}$ & 1.026 & $-22.31^{* * *}$ \\
\hline & $(0.0669)$ & $(0.0566)$ & $(0.0757)$ & $(0.0934)$ & $(2.691)$ \\
\hline \multirow[t]{2}{*}{ Sector $=7$, transport } & $0.761^{* * *}$ & 1.034 & $1.384^{* * * *}$ & $1.754^{* * *}$ & $-4.033^{* * *}$ \\
\hline & $(0.0276)$ & $(0.0762)$ & $(0.0909)$ & $(0.0903)$ & (1.389) \\
\hline \multirow[t]{2}{*}{ Sector $=8$, financial services } & $0.575^{* * *}$ & $0.329^{* * * *}$ & $0.619^{* * * *}$ & $1.156^{*}$ & $-18.27^{* * *}$ \\
\hline & $(0.0416)$ & $(0.0505)$ & $(0.0884)$ & $(0.0906)$ & $(2.270)$ \\
\hline \multirow[t]{2}{*}{ Sector $=9$, social services } & $0.500^{* * * *}$ & $0.229^{* * * *}$ & $0.510^{* * *}$ & $0.857^{*}$ & $-13.38^{* * * *}$ \\
\hline & $(0.0397)$ & $(0.0500)$ & $(0.114)$ & $(0.0796)$ & $(2.516)$ \\
\hline \multirow[t]{2}{*}{ year } & $1.002^{*}$ & 0.998 & $0.997^{* *}$ & $0.993^{* * *}$ & $-0.111^{* * * *}$ \\
\hline & $(0.000821)$ & $(0.00137)$ & $(0.00120)$ & $(0.000879)$ & $(0.0244)$ \\
\hline Number of insured workers & (exposure) & (exposure) & & (exposure) & - \\
\hline Number of injuries & - & - & (exposure) & & - \\
\hline \multirow[t]{2}{*}{ alpha// } & $0.00595^{* * *}$ & $0.00562^{* * *}$ & $0.00362^{* * *}$ & $0.00635^{* * *}$ & - \\
\hline & $(0.000876)$ & $(0.00311)$ & $(0.00350)$ & $(0.00114)$ & - \\
\hline No. observations, $\mathrm{N} \times \mathrm{T}$ & 90 & 90 & 90 & 90 & 90 \\
\hline R-squared & & & & & 0.995 \\
\hline
\end{tabular}

/D2008 = 1 if $\mathrm{T} \geq 2008$ and $=0$ otherwise, //alpha is the dispersion parameter. If the dispersion parameter equals 0 , the model reduces to the simpler Poisson model. If is greater than 0 , the data are overdispersed and are better estimated using a negative binomial model, standard error in parentheses, ${ }^{* * * *} p<0.01,{ }^{* * *} p<0.05,{ }^{*} p<0.1$, source: own calculations. 